Article

\title{
The interactions between an aza-cyclic cerium (III) complex and pUC19 DNA
}

\author{
Min Wang, Lan Yu, Fangzhen Li, Jiaqing Xie* \\ College of Chemistry and Chemical Engineering, Chongqing University of Technology, Chongqing 400054, China
}

\section{A R T I C L E I N F O}

Article history:

Received 18 November 2013

Accepted 30 December 2013

Published 20 April 2014

\section{Keywords:}

Aza-cycle

Cerium

Complex

DNA

Cleavage

\begin{abstract}
A B S T R A C T
A new biomimetic catalyst (M-CYC) is formed from the combination of CYC (a derivative of 1,4,7,10,13,16,19,22,25,28,31-undecaaza-cyclotritriacontane-2,5,8,11,14,17,20,23,26,29,32-undeca acyl) and Ce(III, M) in aqueous solution. The interaction between this complex and DNA was studied using electronic absorption spectroscopy, fluorescence spectroscopy, and gel electrophoresis. The results indicated that $\mathrm{M}-\mathrm{CYC}$ and calf thymus DNA (pUC19 DNA) interacted via intercalation. The apparent binding constant of the complex with DNA was determined to be $2.0 \times 10^{4} \mathrm{~L} / \mathrm{mol}$ at $\mathrm{pH}$ 8.16. Based on gel electrophoresis analysis, M-CYC was shown to nick the circular plasmid pUC19 DNA in the presence of a free radical scavenger. The nicking of DNA serves as a model of hydrolyzed cleavage.
\end{abstract}

(C) 2014, Dalian Institute of Chemical Physics, Chinese Academy of Sciences. Published by Elsevier B.V. All rights reserved.

\section{Introduction}

Nucleic acid (DNA) is an important substance of living organisms, the carrier of genetic information and the material base of gene expression. It plays very important role in organism growth, development and reproduction. The study of nucleic acid cleavage agents is a topic of interest for many researchers in chemistry and molecular biology [1-3]. Metal complexes acting as nucleic acid mimic enzymes are studied for their biological effects on DNA [4-6]. Investigations into the binding mode and mechanisms of DNA-metal complex formation are very important for the application of metal complexes in anti-cancer drugs, molecular biochemistry, and biotechnology [7-11]. Owing to their unique structure and properties, aza-macrocyclic metal complexes have been widely employed for the study of nucleic acid mimic enzymes [12-18]. Generally, the binding mode can be determined by the visible spectra of the interactions between the small molecule and
DNA. The obtained information can prove useful for understanding the interaction of drugs with DNA at a molecular level and helps to provide a theoretical basis for new drug development.

In this work, CYC (cyclosporin, a derivative of 1,4,7,10,13,16, 19,22,25,28,31-undecaaza-cyclotritriacontane-2,5,8,11,14,17, 20,23,26,29,32-undeca acyl) with multi electron donating groups (Scheme 1) was used to form a metal complex with cerium (III, M). The interactions between DNA and this metal complex are reported herein for the first time. Furthermore, compared with other lanthanide metal ions, Ce has relatively low toxicity, and thus, complexes of the type described here may prove useful for the design of new drugs targeting DNA.

\section{Experimental}

\subsection{Absorption spectra}

\footnotetext{
* Corresponding author. Tel: +86-23-62563183; E-mail: xjq8686@163.com This work was supported by the National Natural Science Foundation of China (21173274), Major Science and Technology Project of Zigong City (2013X03), and the Educational Department of Sichuan Government (13ZA0126). 


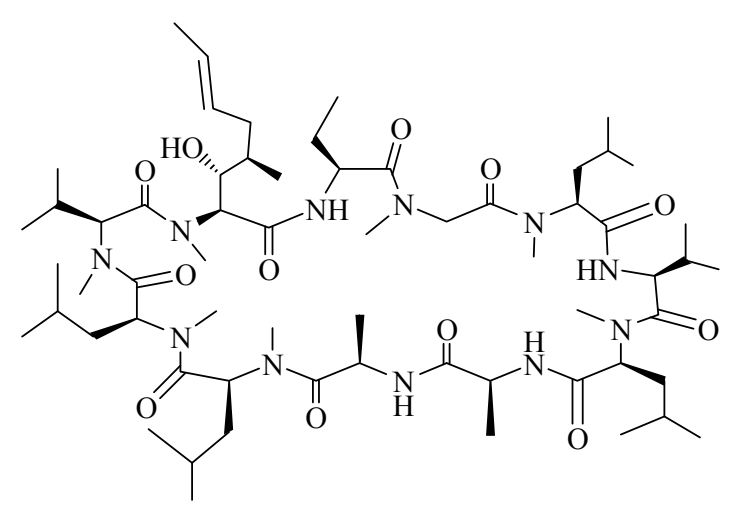

Scheme 1. The structure of the ligand CYC.

Stock solutions of $\mathrm{Ce}\left(\mathrm{NO}_{3}\right)_{3}(3.0 \mu \mathrm{mol} / \mathrm{L})$ and $\mathrm{CYC}(3.0$ $\mu \mathrm{mol} / \mathrm{L}$ ) were prepared at $\mathrm{pH}=8.20$ (Tris-HCl). CYC was provided by Adamas. The absorbance measurements were carried out by scanning the same concentrations of metal Ce(III, M), ligand CYC, and metal complex M-CYC solutions. UV-Vis absorption spectra of the complex with DNA were recorded by keeping the metal complex concentration constant (1.5 $\mu \mathrm{mol} / \mathrm{L}$ ) while varying the DNA concentration in the solution. While measuring the absorption spectra, an equal amount of DNA (stock solution $5.5 \mathrm{mmol} / \mathrm{L}$ ) was added to both the complex solution and the reference solution to eliminate the absorbance of DNA itself. The complex and the DNA solutions were incubated in a water bath for $5 \mathrm{~min}$ before being scanned and the spectra were recorded from 190 to $400 \mathrm{~nm}$. The UV-Vis spectrophotometer used was the TU-1900 from Persee (Beijing, China).

\subsection{Luminescence titrations}

Luminescence experiments for the metal complex were carried out at a fixed Ce(III) concentration $(3.0 \mathrm{ml}, 5.0 \mu \mathrm{mol} / \mathrm{L})$ to which increments of a stock CYC solution ( $0.5 \mathrm{mmol} / \mathrm{L})$ was added by micro pipette every 5 minutes to achieve the following molar ratios: $[\mathrm{M}]:[\mathrm{CYC}]=1: 0,3: 1,2: 1,1: 1,1: 2,1: 3,1: 4$. After addition of $\mathrm{CYC}$, the resulting solution was allowed to excite and scan. Luminescence experiments for the DNA titration was performed at a fixed [M-CYC] concentration $(3.0 \mathrm{ml}, 8.3$ $\mu \mathrm{mol} / \mathrm{L}$ ) to which increments of a stock calf thymus DNA (CT-DNA) solution were added. After addition of CYC, the resulting solution was allowed to equilibrate at $25{ }^{\circ} \mathrm{C}$ in the dark for $5 \mathrm{~min}$ before being excited at $254 \mathrm{~nm}, 800 \mathrm{~V}$ and slit width of $5 \mathrm{~nm}$, and the emission was observed between 270 and 490 nm (Hitachi F-4500, Japan).

\subsection{Gel electrophoresis}

A certain amount of supercoiled pUC19 DNA (Sigma) was treated with Ce(III) complex M-CYC to give a mixture and then it was incubated at $37^{\circ} \mathrm{C}$ for a defined time. Then, the reaction was quenched by adding $6 \times$ loading buffer. Electrophoresis was carried out at $100 \mathrm{~V}$ in $1 \times$ TAE buffer in a mini-gel electrophoresis unit (DYCP-31DN, Beijing, China). Subsequently, the plasmid bands were visualized by viewing the gel under a transilluminator and photographed (Vilber Lourmat, France).

\section{Results and discussion}

\section{1. $U V$-Vis spectra of $M-C Y C$}

Generally, changes of UV-Vis absorption intensity and a red shift of the maximum wavelength can be used to confirm an interaction between metal ions and ligands [19]. Figure 1 shows the absorption spectra of the ligand CYC and Ce ion. It is evident that the absorption intensity of the metal complex is not the summation of the metal ion and ligand. This may be a result of the formation of the M-CYC complex. After one week, the absorption spectra were essentially unchanged, indicating that the formed M-CYC complex was relatively stable.

Fluorescence was employed to study the interactions between the Ce ion and CYC. An increase or a decrease of the fluorescent intensity of the system indicates that an interaction between them occurs, a process that is ascribed to energy transfer and leads to the changes of fluorescent intensity $[20,21]$. The fluorescent spectra were obtained at a fixed concentration of Ce ion and are shown in Fig. 2. It can be seen that the fluorescent intensity of the Ce ion decreases upon the addition of CYC, which indicates that there must be interactions between them.

\subsection{The interactions between $M-C Y C$ and DNA}

Electronic absorption spectroscopy is widely used to determine the binding of complexes with the DNA helix. The non-covalent interactions typically involved between metal complexes and DNA include intercalation binding, groove binding, electrostatic binding, and hydrogen bonding interaction. Generally, an obvious change of hypochromism and red shift in the UV spectra are associated with the binding of a complex to DNA because intercalation involves a stacking interaction between the aromatic chromophore and the DNA base pairs. The magnitudes of the hypochromism and red shift depend on the strength of the intercalative interaction: the stronger the intercalation binding, the more obvious the red

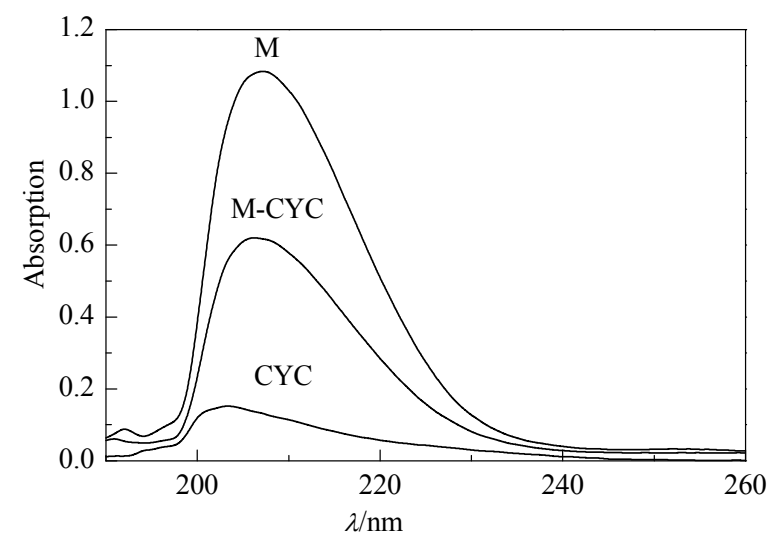

Fig. 1. UV-Vis absorption spectra of $\mathrm{Ce}^{3+}(\mathrm{M})$, ligand (CYC), and complex (M-CYC). $\mathrm{pH}=8.20,37{ }^{\circ} \mathrm{C},[\mathrm{CYC}]=[\mathrm{M}]=1.5 \mu \mathrm{mol} / \mathrm{L},[\mathrm{M}-\mathrm{CYC}]=1.5$ $\mu \mathrm{mol} / \mathrm{L}$. 


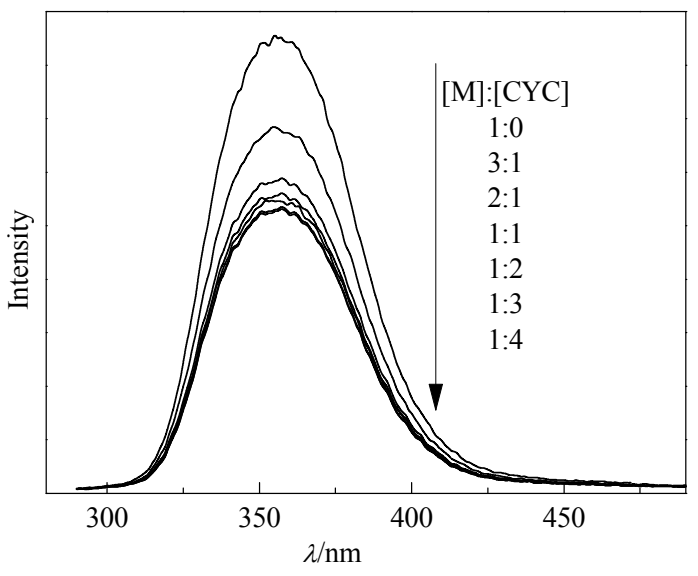

Fig. 2. Fluorescent spectra obtained with increasing amounts of ligand. $\mathrm{pH}=8.20,37^{\circ} \mathrm{C},[\mathrm{M}]=5.0 \mu \mathrm{mol} / \mathrm{L}, \lambda_{\mathrm{ex}}=254 \mathrm{~nm}$.

shift and the hypochromism [22]. A lack of or no red shift in absorption spectra and no obvious hypochromism are usually associated with electrostatic or groove binding. Obvious hyperchromicity in an absorption spectrum is often associated with hydrogen bonding.

Figure 3 shows the UV absorption spectra of M-CYC with CT-DNA. It can be seen that M-CYC exhibited a characteristic peak at $206 \mathrm{~nm}$. When the concentrations of CT-DNA were increased, a considerable decrease in the intensity of the maximum absorption peak and an obvious red shift of about $13 \mathrm{~nm}$ were observed. This may due to the fact that the intercalative binding mode involves a $\pi$ electron stacking interaction between the Ce complex and the DNA base pairs, which leads to the decrease of the energy of $\pi \rightarrow \pi^{*}$ transition and red shift in the absorption spectra. The transition probability of $\pi \rightarrow \pi^{*}$ decreased and thus the hypochromism was observed. Based on the above titration experiments, the binding constant of the complex $\left(K_{\mathrm{b}}\right)$ was calculated by using the following equation [23]:

$$
[\mathrm{DNA}] /\left(\varepsilon_{\mathrm{f}}-\varepsilon_{\mathrm{a}}\right)=[\mathrm{DNA}] /\left(\varepsilon_{\mathrm{f}}-\varepsilon_{\mathrm{b}}\right)+1 / K_{\mathrm{b}}\left(\varepsilon_{\mathrm{f}}-\varepsilon_{\mathrm{b}}\right)
$$

where $\varepsilon_{\mathrm{a}}, \varepsilon_{\mathrm{f}}$, and $\varepsilon_{\mathrm{b}}$ correspond to the extinction coefficient for

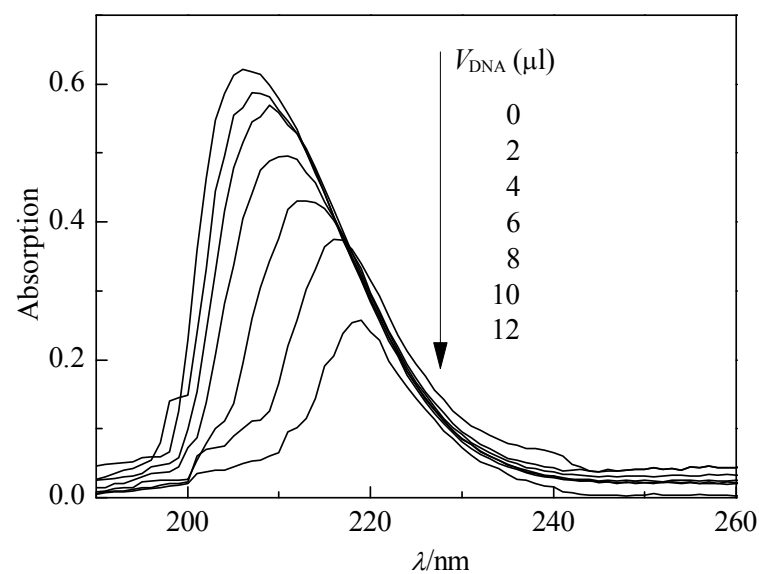

Fig. 3. UV-Vis absorption spectra of the M-CYC complex with increasing amounts of DNA. $\mathrm{pH}=8.20,37^{\circ} \mathrm{C},[\mathrm{M}-\mathrm{CYC}]=1.5 \mu \mathrm{mol} / \mathrm{L},[\mathrm{DNA}]=5.5$ $\mathrm{mmol} / \mathrm{L}$. initial complex concentration for the free metal complex, and the metal complex in the fully bound form, respectively. A plot of [DNA] $/\left(\varepsilon_{\mathrm{a}}-\varepsilon_{\mathrm{f}}\right) \mathrm{vs}$ [DNA] gives $K_{\mathrm{b}}$ from the ratio of the slope to the intercept. The binding constant $K_{\mathrm{b}}$ was determined to be $2.0 \times 10^{4} \mathrm{~L} / \mathrm{mol}$, which is in the range of $10^{4}-10^{6} \mathrm{~L} / \mathrm{mol}$ [24]. Although it is $2-3$ orders of magnitude smaller than that reported for the typical intercalator ethidium bromide [25], this constant is close to $K_{\mathrm{b}}$ value of many other DNA intercalators. Therefore, we concluded that the interaction between the $\mathrm{Ce}$ complex and CT-DNA occurs and the binding mode was intercalative interaction.

Fluorescence can also be used to investigate the interactions between metal complexes and nucleic acids. The changes of the fluorescent spectra are related to the interactions and the magnitudes of the changes depend on the strength of the interactions. Therefore, the fluorescent spectra of the Ce complex were recorded under the conditions of titrating the complex with CT-DNA and the results were shown in Fig. 4.

Upon the addition of CT-DNA, the fluorescent intensity decreased compared with that of the complex alone. This result was contrary to that obtained in Ref. [26]. This may be due to the fact that when the metal complex intercalates to the DNA, the interaction between the metal Ce ion and the negatively charged phosphate DNA backbone leads to the quenching of the luminescence of the Ce complex by DNA resulting in a decrease in the fluorescent intensity.

\subsection{DNA cleavage}

Supercoiled pUC19 DNA, a widely used DNA cleavage substrate, is a circular double stranded DNA (Form I). In gel electrophoresis, supercoiled DNA usually moves faster toward the anode than relaxed DNA because it is tightly coiled and hence more compact, while nicked DNA (Form II) moves more slowly under the same conditions. Therefore, gel electrophoresis can be employed to study the intercalation of a metal complex into DNA since DNA untwisting will not occur when there is only groove binding or electrostatic interactions between DNA and a metal complex.

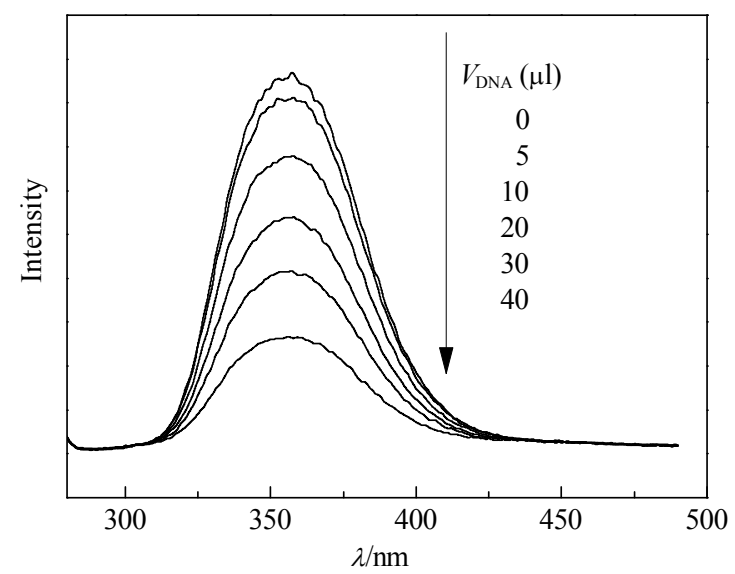

Fig. 4. Fluorescence spectra of the complex with increasing amounts of DNA. $\mathrm{pH}=8.20,20^{\circ} \mathrm{C}, \lambda_{\mathrm{ex}}=254 \mathrm{~nm},[\mathrm{M}-\mathrm{CYC}]=8.3 \mu \mathrm{mol} / \mathrm{L},[\mathrm{DNA}]=5.5$ $\mathrm{mmol} / \mathrm{L}$. 


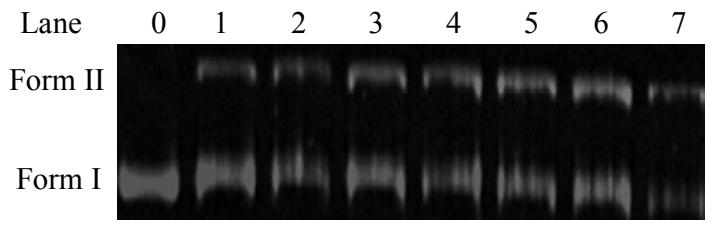

Fig. 5. DNA cleavage in the presence of the metal complex at different time intervals. Lane 0: DNA alone; Lanes 1-7: DNA+ complex, 1, 2, 5, 10, 15,20 , and $25 \mathrm{~h}$, respectively; $[\mathrm{M}-\mathrm{CYC}]=0.75 \mathrm{mmol} / \mathrm{L}, \mathrm{pH}=7.20,37^{\circ} \mathrm{C}$.

Figure 5 shows the mobility of supercoiled pUC19 DNA cleavage by complex M-CYC at different time intervals. There was no DNA cleavage of the control (Lane 0 ) in which the metal complex was absent while the pUC19 DNA (Form I) was efficiently cleaved into the nicked Form II (Lanes 1-7) in the presence of the complex M-CYC. The amount of Form I decreased as the time increased while Form II increased. After 25 $\mathrm{h}$, the supercoiled DNA was almost disappeared. The smeared bands and the lack of small DNA fragments may be a result of the electrostatic interactions between the DNA and the metal complex, which affect the migration rate of the DNA-metal complex. The absence of any linear Form III in the gel may be ascribed to the relatively low activity of complex M-CYC.

Figure 6 shows the supercoiled pUC19 DNA cleavage by the complex M-CYC at different $\mathrm{pH}$ values. The amount of supercoiled DNA at $\mathrm{pH}=7.20$ was less than that observed at other conditions, and the amount of nicked form increased which indicates that the efficacy of the cleavage of the supercoiled DNA by M-CYC was dependent on the $\mathrm{pH}$ value.

In order to explore the DNA cleavage mechanism, all reactions were performed under anaerobic conditions or in the presence of a hydroxyl radical scavenger (DMSO, glycerol, methanol). As shown in Fig. 7, the complex M-CYC can efficiently cleave DNA under aerobic and anaerobic conditions (Lanes 1 and 2) while the DNA cleavage in the presence of $\mathrm{H}_{2} \mathrm{O}_{2}$ in Lane 3 was not as efficient as other conditions. The efficacy of the DNA cleavage was almost the same in the presence of the hydroxyl radical scavenger DMSO (Lane 4), glycerol (Lane 5) or methanol (Lane 6). Therefore, it was likely that the DNA cleavage by the M-CYC complex was carried out via a hydrolytic pathway.

DNA hydrolytic cleavage usually proceeds via nucleophilic substitution. A proposed hydrolytic mechanism of DNA cleavage is shown in Scheme 2. The positive Ce ion in the metal complex attracts a negatively charged $O$ ion in the DNA phosphate group by electrostatic interaction, which was illustrated

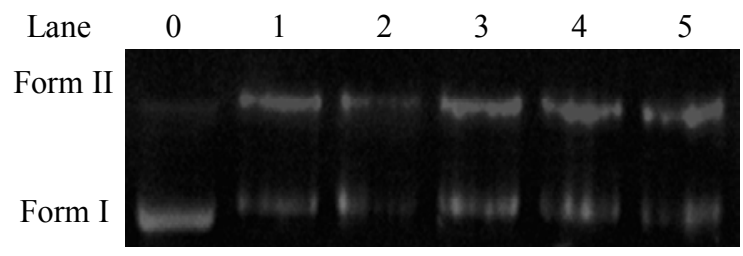

Fig. 6. DNA cleavage in the presence of the complex at different $\mathrm{pH}$ values. Lane 0: DNA alone; Lanes 1-5: DNA + complex, $\mathrm{pH}=6.80,7.20$, $7.40,7.70$, and 8.20 , respectively; $37^{\circ} \mathrm{C}$ for $1 \mathrm{~h}$, $[\mathrm{M}-\mathrm{CYC}]=0.75 \mathrm{mmol} / \mathrm{L}$.

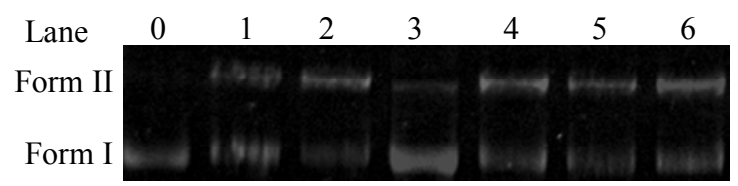

Fig.7. DNA cleavage in the presence of the metal complex and different reagents. Lane 0: DNA alone; Lane 1: complex; Lane 2: complex, fill nitrogen; Lane 3: complex $+\mathrm{H}_{2} \mathrm{O}_{2}$; Lane 4: complex + DMSO; Lane 5: complex + glycerol; Lane 6: complex + methanol. $37{ }^{\circ} \mathrm{C}$ for $1 \mathrm{~h}, \mathrm{pH}=$ $7.80,[\mathrm{M}-\mathrm{CYC}]=0.75 \mathrm{mmol} / \mathrm{L}$.

by the fluorescent quenching observed in this work. Then the nucleophilic hydroxyl produced from the water molecule associated with the Ce ion attacks the phosphorus atom of DNA and then promotes the cleavage of the $\mathrm{P}-\mathrm{O}$ bond to generate the product.

\section{Conclusions}

The interaction between the cerium (III) complex (M-CYC) consisting and DNA was studied. The UV-Vis absorption and fluorescent results indicate that the metal complex interacts with CT-DNA by intercalation. In addition, M-CYC complex can efficiently cleave supercoiled pUC19 DNA into a nicked DNA under certain conditions. The DNA cleavage proceeded to the same extent in the presence of hydroxyl radical scavengers, which indicates that the DNA cleavage by M-CYC was most likely via the hydrolytic pathway. Further research is required to confirm the DNA hydrolysis cleavage mechanism proposed herein.

\section{References}

[1] Li F L, Shi S, Yao T M. Chemisry (李风莲, 石硕, 姚天明. 化学通报), 2008: 731

[2] Jiang B Y, Wang M, Li C, Xie J Q. Med Chem Res, 2013, 22: 3398

[3] Shen H Y, Zhu F, Shi W, Chen Z, Pan Q Q. Acta Chim Sin (沈吴宇, 朱

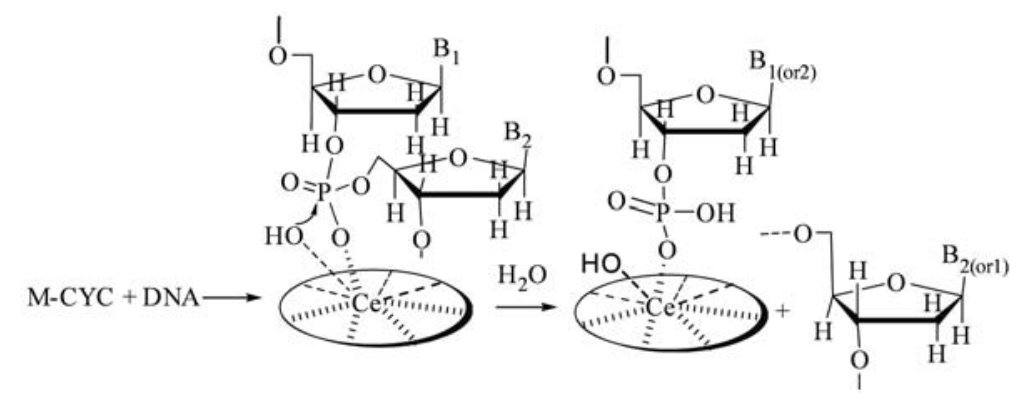

Scheme 2. pUC 19 DNA cleavage mechanism catalyzed by the metal complex. 


\title{
Graphical Abstract
}

Chin. J. Catal., 2014, 35: 524-531 doi: 10.1016/S1872-2067(14)60017-6

The interaction between the aza-cyclic cerium(III) complex and pUC19 DNA

Min Wang, Lan Yu, Fangzhen Li, Jiaqing Xie*

Chongqing University of Technology

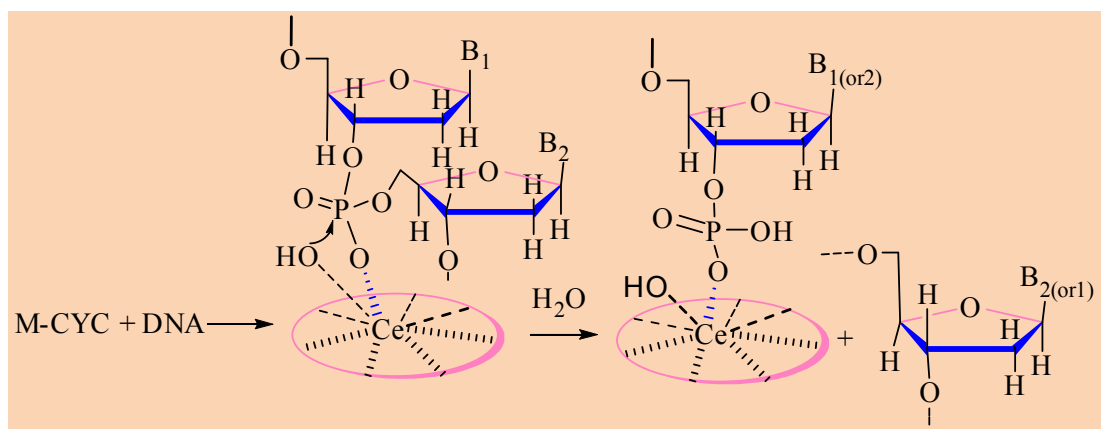

A new biomimetic catalyst M-CYC made from Ce(III) metal ion and cyclosporin was constructed and used as a catalyst in the cleavage of plasmid pUC19 DNA. The interactions between M-CYC and DNA were investigated by UV-Vis absorption and fluorescence spectroscopy.

凡, 施炜, 陈真, 潘青青. 化学学报), 2010, 68: 1719

[4] Kimura E, Aoki S, Koike T. J Am Chem Soc, 1997, 119: 3068

[5] Ding C, Chen Y F, Liu M, Song H T, Zhou H, Pan Z Q. Chin J Inorg Chem, 2012, 28: 801

[6] Li J H, Dong J F, Cui H, Xu T, Li L Z. Transition Met Chem, 2012, 37: 175

[7] Patel M N, Patel S H, Pansuriya P B. Med Chem Res. 2011, 20: 1371

[8] Okamoto A, Tanabe K, Saito I. J Am Chem Soc, 2002, 124: 10262

[9] Zhu L, Peng B, Ling Y, Lin Y B. Acta Chim Sin (朱莉, 彭斌, 凌友, 林 原斌. 化学学报), 2008, 66: 2705

[10] Liu J, Xu D H, Mei W J, Pu H L, Huang J W, Ji L N. Chem J Chin Univ (刘杰, 许东辉, 梅文杰, 蒲含林, 黄锦汪, 计亮年. 高等学校化学 学报), 2001, 22: 1446

[11] Rosenberg B, Van Camp L. Cancer Res, 1970, 30, 1799

[12] Zou M, Liu S W, Zhou C Q. Acta Chim Sin (邹敏, 刘叔文, 周春琼. 化学学报), 2010, 68: 481

[13] Wen X M, Hu H, Zhou H, Pan Z Q. Chin J Inorg Chem (文小明, 胡虹, 周红, 潘志全. 无机化学学报), 2012, 28: 1985

[14] Bazzicalupi C, Bencini A, Bianchi A, Borri C, Danesi A, Garcia-España E, Giorgi C, Valtancoli B. J Org Chem, 2008, 73: 8286

[15] Liang F, Wei J, Li Z Y, Wu C T, Zhen C Y, Sun M X. Chem J Chin Univ (梁峰, 魏俊, 李朝阳, 吴成泰, 郑从义, 孙蒙祥. 高等学校化学学 报), 2004, 25: 470
[16] Du J, Wu Z L, Jia M, Li Y Z, Wang X Y, Guo Z J. Chin J Inorg Chem (杜 俊, 吴子怡, 贾默, 李一志, 王晓勇, 郭子建. 无机化学学报), 2008, 24: 1669

[17] Li F L. [MS Dissertation]. Nanjing: Tongji University (李凤莲. [硕士 学位论文]. 南京: 同济大学), 2008

[18] Wang C Z, Feng X M, Shi M L, Geng Z R. Chin J Inorg Chem, 2012, 28: 839

[19] Li J Z, Xie J Q, Li S X, Zeng W, Zeng X C, Qin S Y. Acta Chim Sin (李建 章, 谢家庆, 李慎新, 曾伟, 曾宪诚, 秦圣英. 化学学报), 2005, 63: 114

[20] Wang H T, Hu T T, Zhang Q L, Liu J H, Ren X Z, Li C H, Wang F, Zhang P X. Acta Chim Sin (王海滔, 胡婷婷, 张黔玲, 刘剑洪, 任祥 忠, 李翠华, 王芳, 张培新. 化学学报), 2008, 66: 1565

[21] Huang Y, Yang R D, Yan L. J Chin Rare Earth Soc (黄勇, 杨汝栋, 阎 兰. 中国稀土学报), 2002, 20(Z3): 17

[22] Pyle A M, Rehmann J P, Meshoyrer R, Kumar C V, Turro N J, Barton J K. J Am Chem Soc, 1989, 111: 3051

[23] Kumar C V, Aauncion E H. J Am Chem Soc, 1993, 115: 8547

[24] Berman HM, Young PR. Annu Rev Biophys Bioeng, 1981, 10: 87

[25] Satyanarayana S, Dabrowiak J C, Chaires J B. Biochemistry, 1992, 31: 9319

[26] Ye Y, Hu J M, Zeng Y E, Yan Z H, Chen J. Chin J Inorg Chem (叶勇, 胡 继明, 曾云鹗, 严振寰, 陈建. 无机化学学报), 1998, 14: 84

\section{氮杂大环铈(III)配合物与pUC19 DNA的相互作用}

\author{
王 敏, 俞 兰, 李方珍, 谢家庆 ${ }^{*}$ \\ 重庆理工大学化学化工学院, 重庆400054
}

摘要: 以一种 $1,4,7,10,13,16,19,22,25,28,31$-十一氮杂 $2,5,8,11,14,17,20,23,26,29,32-$ 一一酰基-环三十三烷的衍生物(CYC)为配体, 在 溶液中和 $\mathrm{Ce}(\mathrm{III}, \mathrm{M})$ 离子形成氮杂大环铈配合物(M-CYC)作为仿生催化剂, 通过紫外光谱法、荧光光谱法和凝胶电泳法研究了 M-CYC配合物与DNA的相互作用. 结果表明, M-CYC与小牛胸腺DNA (CT DNA) 以嵌插方式相互作用, 在 $\mathrm{pH}=8.16$ 的缓冲体系 中, 其结合常数 $K_{\mathrm{b}}=2.0 \times 10^{4} \mathrm{~L} / \mathrm{mol}$. 凝胶电泳结果表明, 当自由基捕捉剂存在时, M-CYC可将超螺旋pUC19 DNA切割为缺刻型 DNA, 其切割方式为水解切割.

关键词: 氮杂大环; 铈(III); 配合物; DNA; 切割 
收稿日期: 2013-11-18. 接受日期: 2013-12-30. 出版日期: 2014-04-20.

*通讯联系人. 电话: (023)62563183; 电子信箱: xjq8686@163.com

基金来源：国家自然科学基金项目(21173274); 自贡科技局重点计划项目(2013X03); 四川教育厅项目(13ZA0126).

本文的英文电子版由Elsevier出版社在ScienceDirect上出版(http://www.sciencedirect.com/science/journal/18722067).

\section{1. 前言}

核酸(DNA)是生物体的重要组成物质、遗传信息的 携带者和基因表达的物质基础, 它对生物的生长、发育 和繁育等活动具有十分重要的作用. 核酸切割试剂的研 究是化学和分子生物学中最为活跃的前沿领域之一 ${ }^{[1-3]}$. 金属配合物作为一种核酸模拟酶, 对DNA常会诱发生物 效应; 因此, 金属配合物作为人工核酸酶的研究也越来 越受到人们的广泛关注 ${ }^{[4-6]}$. 研究金属配合物和DNA相 互作用的方式和机理, 对探索配合物在抗癌药物、分子 生物学、生物工程技术等领域的应用具有重要的意 $义^{[7-11]}$. 由于特殊的结构和性质, 大环多胺金属配合物 已被广泛应用到核酸模拟酶的研究中 ${ }^{[12-18]}$. 通过考察小 分子与DNA相互作用的光谱学现象, 可以确定两者的作 用方式, 有助于从分子水平上了解药物的作用机理, 进 而为开发新药提供理论依据.

本文所用的 $1,4,7,10,13,16,19,22,25,28,31$-十一氮杂 环三十三烷配体(俗名环狍菌素, 缩写CYC)属于多胺类 物质, 具有多供电子基的大环结构(见图式1), 有利于与 金属离子形成金属配合物. 到目前为止, 环孢菌素与金 属Ce(III)形成的M-CYC配合物与DNA的作用研究未见 报道. 此外, Ce属于轻稀土元素, 与其他稀土元素相比, 毒性较低, 可能成为新型抗癌药物的活性成分. 因此, 研 究M-CYC对DNA的作用机制对新型药物设计具有重要 的理论价值.

\section{2. 实验部分}

\section{1. 紫外可见吸收光谱}

用 Tris- $\mathrm{HCl}$ 缓冲溶液溶解硝酸铈, 配成溶液 3.0 $\mu \mathrm{mol} / \mathrm{L}$, 用 $\mathrm{HCl}$ 和 $\mathrm{NaOH}$ 调节溶液的 $\mathrm{pH}$ 值为 8.20. 同法配 制配体CYC (Adamas 公司)溶液 $(3.0 \mu \mathrm{mol} / \mathrm{L})$. 分别取上 述 $\mathrm{Ce}(\mathrm{III})$ 离子溶液和配体 $\mathrm{CYC}$ 溶液各 $3.0 \mathrm{ml}$ 混合, 得到 配合物M-CYC溶液 $(1.5 \mu \mathrm{mol} / \mathrm{L})$. 以 Tris-HCl缓冲溶液作 参比, 分别测量浓度均为 $1.5 \mu \mathrm{mol} / \mathrm{L}$ 的 $\mathrm{Ce}(\mathrm{III})$ 离子溶液、 配体CYC溶液、金属配合物溶液的电子吸收光谱.

在紫外可见光谱仪(TU-1900, 北京普析)的参比池 中加入 $3.0 \mathrm{ml}$ Tris-HCl缓冲溶液 $(\mathrm{pH}=8.20)$, 样品池加入 $3.0 \mathrm{ml}$ 的配合物 $\mathrm{M}-\mathrm{CYC}$ 溶液 $(1.5 \mu \mathrm{mol} / \mathrm{L})$. 用微量移液枪
每隔 $5 \mathrm{~min}$ 向参比池和样品池中各加入 $2 \mu \mathrm{l}$ 的CT-DNA储 备液 $(5.5 \mathrm{mmol} / \mathrm{L})$, 使DNA与配合物的浓度比值不断增 加. 每次加入DNA后, 检测其在190-400 nm范围内的紫 外可见吸收光谱.

\section{2. 荧光光谱的测定}

用一定 $\mathrm{pH}$ 值的 Tris 缓冲溶液配制小牛胸腺 DNA(CT-DNA), 金属Ce(M)离子, M-CYC混合溶液, 摇 匀, 备用.

样品池加入 $3.0 \mathrm{ml} \mathrm{Ce}(\mathrm{III})$ 离子溶液 $(5.0 \mu \mathrm{mol} / \mathrm{L})$. 用 微量移液枪每隔 $5 \mathrm{~min}$ 向样品池中加入一定体积的 CYC 储备液 $(0.5 \mathrm{mmol} / \mathrm{L})$, 分别使得 $[\mathrm{M}]:[\mathrm{CYC}]=1: 0,3: 1$, $2: 1,1: 1,1: 2,1: 3,1: 4$. 每次加入 $\mathrm{CYC}$ 后, 检测发射光谱的 变化.

在Hitachi F-4500型荧光光谱仪的比色皿中加入 3.0 $\mathrm{ml}$ 的M-CYC溶液 $(8.3 \mu \mathrm{mol} / \mathrm{L})$, 用DNA储备液进行滴定, 摇匀, 使DNA与M-CYC配合物的浓度比值不断增大. 每 次混合均匀约 $5 \mathrm{~min}$ 后, 检测发射光谱的变化. 测试条 件: 室温, 激发波长 $254 \mathrm{~nm}$, 发射波长270-490 nm, 电压 $800 \mathrm{~V}$, 狭缝 $5 \mathrm{~nm}$.

\section{3. 凝胶电泳}

实验所用DNA为超螺旋质粒pUC19 DNA(Sigma公 司). 在不同的酸度、配合物浓度条件下, DNA与M-CYC 混合均匀, 使混合液在 $37{ }^{\circ} \mathrm{C}$ 下反应一定时间. 加入溴酚 兰溶液使反应终止. 取一定体积的反应液加入到样品孔 中, 在电泳槽中, 以 TAE缓冲溶液为电极缓冲溶液, 溴酚 兰溶液作为电泳过程的指示标志, 在 $100 \mathrm{~V}, 50 \mathrm{~mA}$ 的恒 压恒流下电泳一段时间 (电泳仪为北京六一厂的 DYCP-31DN型)，在成像系统(法国Vilber Lourmat公司) 中观察结果并成像记录.

\section{3. 结果与讨论}

\subsection{M-CYC的形成}

通常, 如果配体的UV-Vis 吸收峰强度改变, 波长红 移, 可以认为金属离子与配体发生了结合作用 ${ }^{[19]}$. 图 1 是配体CYC和金属Ce离子作用的UV-Vis 谱图. 由图可 见, 当CYC配体与金属Ce离子混合后, 溶液的紫外吸收 值并不是同一条件下配体和金属离子的总和, 可以推测, 两者混合后形成了新的金属Ce配合物. 将混合溶液放 
置一周后再进行紫外测试, 其吸收值没有明显变化, 由 此可见, 金属Ce配合物在溶液中较为稳定.

荧光光谱法也可以用来研究金属离子与配体间的 作用机制. 当金属离子与配体作用后, 如果体系的苂光 强度增强或者减弱, 表明两者发生了结合作用. 这是由 于金属离子和配体之间发生了能量转移, 进而会引起配 合物的荧光减弱或者增强 ${ }^{[20,21]}$. 图2为金属离子浓度不 变时, 金属 $\mathrm{Ce}$ 离子与配体作用的苂光图谱. 可以看出, 加入配体后金属Ce离子的荧光强度有较大程度的降低. 表明金属离子与配体间发生了结合作用.

\subsection{M-CYC与DNA的相互作用}

UV-Vis光谱是判断化合物相互作用的有效手段, 当 电子受体和电子给体生成基态复合物时, UV-Vis光谱会 发生明显的变化. 小分子与双螺旋DNA结合方式主要 有嵌插作用、静电相互作用、沟槽式结合和氢键作用等. 如果配合物与DNA发生嵌插作用, 则配合物紫外光谱吸 收峰的位置发生红移, 强度减小. 红移与减色效应强弱 也能反映出配合物插入DNA能力的大小, 插入能力越 强, 红移与减色效应越大 ${ }^{[22]}$. 若发生静电或沟槽作用, 则配合物的紫外吸收峰将不产生红移或忽略不计, 且减 色效果不明显. 若发生氢键作用, 则配合物的紫外吸收 峰呈现出明显的增色效应.

Tris缓冲溶液中 M-CYC和DNA作用的紫外光谱见 图3. 可以看出, M-CYC的特征吸收峰在 $206 \mathrm{~nm}$ 处. 随着 DNA浓度的增加, 吸收峰明显红移, 最大可达 $13 \mathrm{~nm}$, 并 且出现明显的减色现象. 这是因为配体的插入部分与 DNA碱基对可发生 $\pi$ 电子堆积, 配体的空轨道 $\pi$ 歹碱基 的电子轨道发生偶合, 使能级下降, 导致 $\pi \rightarrow \pi *$ 跃迁能量 减少, 从而产生红移现象. 同时, 偶合后的 $\pi$ *轨道因部分 填充电子, 使 $\pi \rightarrow \pi *$ 跃迁几率减少, 产生减色效应. 通过 DNA对配合物的电子光谱滴定实验, 能够根据以下方程 ${ }^{[23]}$ 求得配合物与 DNA 的结合常数 $K_{\mathrm{b}}$ : [DNA] $/\left(\varepsilon_{\mathrm{f}}-\varepsilon_{\mathrm{a}}\right)=$ $[\mathrm{DNA}] /\left(\varepsilon_{\mathrm{f}}-\varepsilon_{\mathrm{b}}\right)+1 / K_{\mathrm{b}}\left(\varepsilon_{\mathrm{f}}-\varepsilon_{\mathrm{b}}\right)$, 其中 $\varepsilon_{\mathrm{a}}, \varepsilon_{\mathrm{f}}$ 和 $\varepsilon_{\mathrm{b}}$ 分别表示初始浓 度配合物、自由配合物和完全结合后配合物的摩尔吸收 系数. 以 $[\mathrm{DNA}] /\left(\varepsilon_{\mathrm{f}}-\varepsilon_{\mathrm{a}}\right)$ 对 $[\mathrm{DNA}]$ 作图, 斜率与截距的比值 即为 $K_{\mathrm{b}}$. 计算结果为 $K_{\mathrm{b}}=2.0 \times 10^{4} \mathrm{~L} / \mathrm{mol}$, 该值刚好在 $10^{4}-10^{6} \mathrm{~L} / \mathrm{mol}$ 的范围 内 ${ }^{[24]}$, 虽然比以经典插入方式与 DNA 结合的溴化乙啶低 1-2个数量级 ${ }^{[25]}$, 但与很多DNA 嵌入物的 $K_{\mathrm{b}}$ 值相近. 这表明该配合物与DNA有一定的 结合作用, 且以嵌插的方式结合.

荧光光谱法也是研究化合物与核酸作用的重要辅 助方法. 若该物质与DNA 结合后, 苂光光谱发生变化,
说明该化合物与DNA之间发生了某种方式的结合, 光谱 变化幅度的大小反映了化合物与DNA作用的强弱.

因此, 在M-CYC浓度不变情况下, 在配合物溶液中 逐渐加入CT-DNA滴定, 考察配合物与CT-DNA的作用 情况, 结果见图4. 可以看出, 随着CT-DNA浓度的增大, 配合物M-CYC的荧光强度明显降低. 通常金属配合物 以插入方式与DNA结合会导致配合物的苂光增强 ${ }^{[26]}$. 此结果相反, 很可能是伴随金属配合物插入的同时, DNA带负电荷的聚合阴离子磷酸骨架与配合物的金属 Ce离子发生作用, 导致配合物被高负电荷阴离子DNA淬 灭, 从而使其苂光强度降低.

\subsection{M-CYC对DNA的剪切作用}

一般情况下, pUC19 DNA为共价闭环超螺旋构型 (Form I), 结构紧密, 在电泳中向正极方向移动的速率较 大. 金属配合物与质粒DNA作用, 导致DNA双螺旋链解 旋, DNA解旋后产生开环缺刻型DNA(Form II), 其结构 相对松散, 相同条件下电泳移动速率较慢. 因此, 电泳方 法可以作为研究金属配合物与DNA插入结合的研究方 法. 当配合物以沟面或静电作用与DNA结合时,一般不 会引起DNA超螺旋的解旋.

图 5 为配合物 $\mathrm{M}-\mathrm{CYC}$ 与 DNA 反应不同时间的电泳 成像图. 可以看出, 用琼脂糖凝胶电泳研究M-CYC配合 物对pUC19 DNA的切割作用时, DNA被切割的效果与 配合物和DNA反应时间的长短有关: 反应时间较短时, 配合物对DNA的切割作用较小; 当反应时间较长时, 质 粒DNA的Form I构型减少, 而Form II构型不断增多, 说 明配合物切割超螺旋质粒DNA随反应时间的增长剪切 越彻底. 当反应时间达 $25 \mathrm{~h}$ 时, Form I接近完全消失. 同 时发现, 实验中DNA 电泳条带发生弥散, 但没有获得 DNA小片段, 原因可能是带正电荷的配合物与带负电荷 的DNA发生静电结合而影响了在凝胶中的迁移速率, 从 而在电泳时发生弥散. 在图 5 中并未出现线型 DNA(FormIII), 可能与配合物切割活性有关. 图6为配合 物对pUC19 DNA切割的酸度梯度电泳图. 可见, 反应体 系的酸度对配合物切割pUC19 DNA具有较大的影响. 在 $\mathrm{pH}$ 为 7.20时, Form I型DNA最少, 而Form II增多, 说明 质粒pUC19 DNA被切割的效果与反应体系的酸度有关.

为了进一步探索配合物对DNA的切割机理, 我们设 计在无氧条件, 即 $\mathrm{N}_{2}$ 保护条件下M-CYC与DNA反应, 且 在反应体系中加入羟基自由基捕捉剂(DMSO, 甘油, 甲 醇), 判断DNA切割是否经过产生羟基自由基的途径. 结 果如图7所示, 配合物能够在充 $\mathrm{N}_{2}$ 除氧条件下自由切割 
DNA, 泳道1和 2 ; 泳道3加入双氧水后, DNA的切割变得 不明显; 当加入羟基自由基捕捉剂后, 配合物对DNA的 切割几乎不受影响, 表明该配合物对DNA的切割可能是 水解切割机理.

DNA水解断裂通常是一个亲核取代反应过程，因 此我们提出如图式2所示的水解剪切机理. 配合物中带 有正电荷的金属Ce离子通过静电吸引与DNA磷酸基上 的 $\mathrm{O}$ 原子作用(产生配合物的苂光淬灭现象), 亲核物种 $\mathrm{OH}^{-}$(由金属离子活化后的水分子离解产生)进攻P原子,
促进P-O键发生断裂形成产物.

\section{4. 结论}

研究了以 $\mathrm{CYC}$ 为配体的金属 Ce配合物 $\mathrm{M}-\mathrm{CYC}$ 与 DNA的相互作用. 荧光法和紫外光谱结果表明, M-CYC 配合物通过嵌插方式与DNA结合, 并在一定条件下, 能 显著地将超螺旋pUC19 DNA切割为缺刻型DNA, 加入 自由基捕捉剂情况下, 切割效果不受影响, 表明其切割 方式为水解切割. 但其机理有待进一步深入研究. 